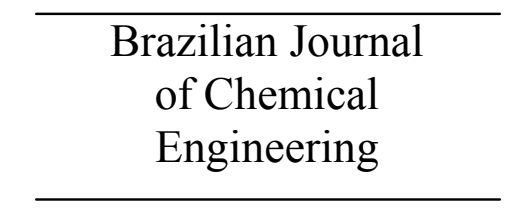

ISSN 0104-6632

Printed in Brazil

www.abeq.org.br/bjche

Vol. 28, No. 02, pp. $305-312$, April - June, 2011

\title{
SUPERCRITICAL FLUID EXTRACTION OF VOLATILE AND NON-VOLATILE COMPOUNDS FROM Schinus molle L.
}

\author{
M. S. T. Barroso, G. Villanueva, A. M. Lucas, G. P. Perez, R. M. F. Vargas, \\ G. W. Brun and E. Cassel ${ }^{*}$ \\ Faculdade de Engenharia, Pontifícia Universidade Católica do Rio Grande do Sul, \\ Phone + (55) (51) 3320-3653, Fax: + (55) (51) 3320-3625, \\ Avenida Ipiranga 6681, Pr. 30, CEP: 90619-900, Porto Alegre - RS, Brasil; \\ E-mail: cassel@pucrs.br
}

(Submitted: November 19, 2010 ; Revised: February 23, 2011 ; Accepted: February 25, 2011)

\begin{abstract}
Schinus molle L., also known as pepper tree, has been reported to have antimicrobial, antifungal, anti-inflammatory, antispasmodic, antipyretic, antitumoural and cicatrizing properties. This work studies supercritical fluid extraction (SFE) to obtain volatile and non-volatile compounds from the aerial parts of Schinus molle L. and the influence of the process on the composition of the extracts. Experiments were performed in a pilot-scale extractor with a capacity of $1 \mathrm{~L}$ at pressures of 9, 10, 12, 15 and $20 \mathrm{MPa}$ at $323.15 \mathrm{~K}$. The volatile compounds were obtained by $\mathrm{CO}_{2}$ supercritical extraction with moderate pressure $(9 \mathrm{MPa})$, whereas the non-volatile compounds were extracted at higher pressure (12 to $20 \mathrm{MPa})$. The analysis of the essential oil was carried out by GC-MS and the main compounds identified were sabinene, limonene, D-germacrene, bicyclogermacrene, and spathulenol. For the non-volatile extracts, the total phenolic content was determined by the Folin-Ciocalteau method. Moreover, one of the goals of this study was to compare the experimental data with the simulated yields predicted by a mathematical model based on mass transfer. The model used requires three adjustable parameters to predict the experimental extraction yield curves.

Keywords: Supercritical extraction; Schinus molle L; Essential oil; Phenolic compounds.
\end{abstract}

\section{INTRODUCTION}

The pepper tree (Schinus molle L.) is a tree native to the Peruvian Andes (Huerta et al., 2010) and is widely grown in tropical and subtropical countries (Wimalaratne et al., 1996). The leaves of this tree are the source for extraction of the essential oil used in popular medicine and as a repellent and bioinsecticide (Ferrero et al., 2007; Huerta et al., 2010). The volatile oil is reported to have antimicrobial, antispasmodic, antipyretic, antifungal and cicatrizing properties (Marongiu et al., 2004; Ferrero et al., 2006; Hayoni et al., 2008).

Supercritical fluid extraction is a technique widely used in separation processes of natural products, where the solvent usually used is not toxic, such as carbon dioxide. The supercritical fluid has properties such as high diffusivity, low viscosity and low surface tension, which gives it attractive characteristics as a solvent for the extraction of components from the solid matrix (Taylor, 1996). Advantages of the use of carbon dioxide under supercritical conditions are selectivity (Cardozo et al, 2007; Azevedo et al., 2008) and solubility (Brennecke and Eckert, 1989). Marongiu et al. (2004) studied the $\mathrm{CO}_{2}$ supercritical extraction of $S$. molle and indicated that increasing the $\mathrm{CO}_{2}$ density permits the extraction of compounds of high molecular weight.

Traditionally, the $S$. molle volatile compounds are extracted by hydrodistillation (Santos et al, 2007;

*To whom correspondence should be addressed 
Zahed et al., 2010) or by steam distillation (Bendaoud et al., 2010) in a Clevenger-type apparatus and the isolated oil is dried over anhydrous $\mathrm{Na}_{2} \mathrm{SO}_{4}$. With regard to non-volatile compounds, the extracts are conventionally obtained by maceration using methanol (Marzouk et al., 2006; Ferrero et al., 2007), ethanol (Huerta et al., 2010), or n-hexane (Ferrero et al., 2007) as solvent. The extracts are filtered and evaporated to dryness under low pressure.

The mathematical modeling of the supercritical extraction process is an inevitable step in designing industrial plants with good operational conditions. A mathematical modeling is performed by establishing differential equations based on the mass transfer in the solvent fluid phase and in the solid phase along the bed. Models based on differential mass balance have been widely used to describe supercritical extraction. Differential equations are obtained from mass balances achieved over an infinitesimal element of the extractor according to a hypothesis frame. On the basis of different hypotheses, various models were constructed (Reverchon, 1996; Martinez et al., 2003). The approach, based on differential mass balances along the extraction bed, requires mass transfer mechanisms and an equilibrium relationship. In models of this kind, adjustable parameters derived from experimental extraction data are required (Marrone et al., 1998; Vargas et al., 2006).

Supercritical fluid extraction is influenced by operational conditions. These conditions are bed porosity, solvent flow, temperature, pressure, and particle size. The objective of this study is to analyze the supercritical fluid extraction from twigs and leaves of $S$. molle through process variable evaluation in order to define the appropriated pressure conditions with regard to the yield and composition of the extracts, keeping all other variables constant. The purpose was also to evaluate the mass transfer aspects of supercritical fluid extraction using a mathematical model. The model proposed by Sovová (2005) was chosen to simulate the extraction process.

\section{MATERIAL AND METHODS}

\section{Supercritical Extraction}

The raw material, consisting of leaves and twigs, was supplied by Tekton Óleos Essenciais Ltda. in the state of Rio Grande do Sul in southern Brazil. The plant material was dried at $313.15 \mathrm{~K}$ during $48 \mathrm{~h}$. A sample of $200 \mathrm{~g}$ of dried and milled material with an average particle diameter of $2 \times 10^{-3} \mathrm{~m}$ was used for extraction of volatile and non-volatile compounds in a supercritical extraction pilot plant (Cassel et al., 2010).
The solvent used was $99.9 \%$ carbon dioxide (Air Products) with a flow rate of $1.38 \times 10^{-4} \mathrm{~kg} \mathrm{~s}^{-1}$ through the extraction vessel. The extractor temperature was $323.15 \mathrm{~K}$ and the pressure range was between $9 \mathrm{MPa}$ and $20 \mathrm{MPa}$. The temperature was chosen on the basis of previous results on SFE of similar matrixes (Cassel et al., 2010; Marongiu et al., 2004). The temperature of the separator vessel was $273.15 \mathrm{~K}$.

A schematic diagram of the experimental apparatus is shown in Figure 1. It includes a positive liquid displacement pump (Thar P-200, USA) for solvent delivery $(0.02-0.20 \mathrm{~kg} / \mathrm{min})$, a $1000 \mathrm{~mL}$ high-pressure extraction vessel, and a separator flask. The extraction vessel is supplied with a heating jacket and an automated temperature controller. Heating tapes were used throughout the apparatus to maintain a constant temperature in the extraction section. Flow rates and accumulated gas volumes passing through the apparatus were measured using a mass flowmeter. Micrometering valves were used for flow control throughout the apparatus. Heating tapes with automated temperature control were also used around this valve to prevent both freezing of the solvents and solid solute precipitation following depressurization. Pressure in the extractor was monitored with a digital transducer system (Novus 8800021600 ) acquired from Novus Produtos Eletrônicos (Brazil) with a precision of \pm 1.0 bar and the temperature controller was connected to thermocouples (PT-100, with an accuracy of $0.5 \mathrm{~K}$ ).

\section{Chemical Analysis}

The composition of the oil was determined by GC on an Agilent 7890A gas chromatograph equipped with an Agilent 5975C mass spectrometer. The capillary column was a HP-5MS (Agilent $\mathrm{J} \& \mathrm{~W}$ ) silica capillary column $(30 \mathrm{~m}$ x $250 \mu \mathrm{m}$ i.d., $0.25 \mu \mathrm{m}$ phase thickness), coated with $5 \%$ phenyl methyl silane; column temperature $60^{\circ} \mathrm{C}$ for $8 \mathrm{~min}$, raised to $180^{\circ} \mathrm{C}$ at $3^{\circ} \mathrm{C} / \mathrm{min}, 180-250^{\circ} \mathrm{C}$ at $20^{\circ} \mathrm{C} / \mathrm{min}$, then $250^{\circ} \mathrm{C}$ for $10 \mathrm{~min}$. Injector temperature $250^{\circ} \mathrm{C}$; detector temperature $280^{\circ} \mathrm{C}$; injection mode, split; split ratio 1:55; volume injected, $0.2 \mu \mathrm{L}$ of the oil. Carrier gas was Helium, flow rate $0.8 \mathrm{~mL} / \mathrm{min}$; interface temperature $250^{\circ} \mathrm{C}$; MS mode EI; EI voltage $70 \mathrm{eV}$; acquisition mass range, $\mathrm{m} / \mathrm{z} 40-450$.

The components of the oil were identified by comparison of their Retention Index (RIs) on the column, determined in relation to a homologous series of n-alkanes C8-C20 (Fluka Analytical), with those reported in the literature (Jennings and Shibamoto, 1980; Davies, 1990). Comparison of fragmentation patterns in the mass spectra with those stored in the GC-MS databases (Adams, 2007) was also performed. 


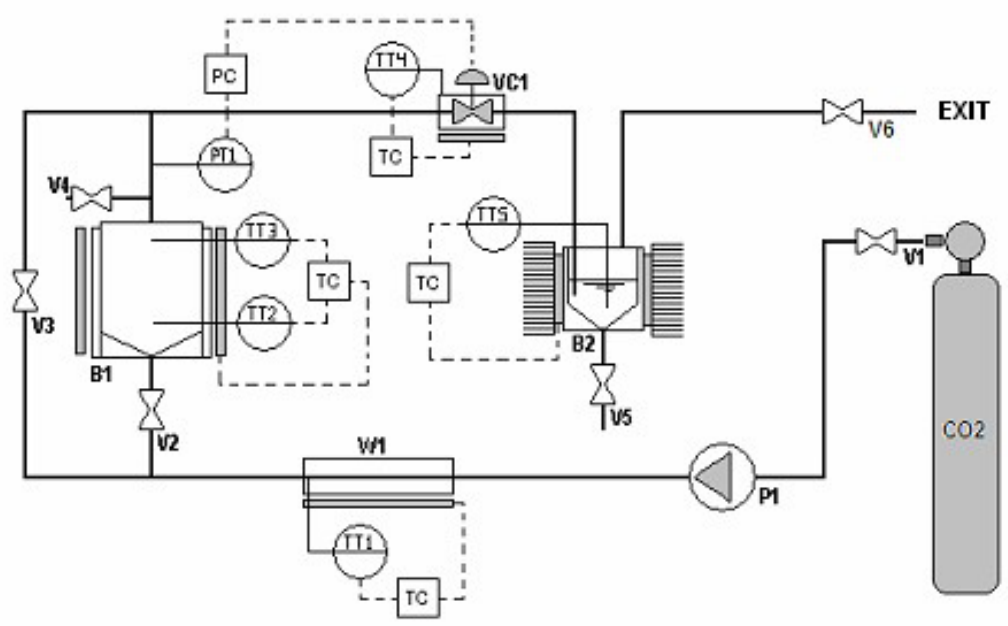

P1 - high pressure pump;

W1- preheater;

B1 - extraction vessel;

B2 - separation vessel;

VC1- micrometering;

TC - temperature controllers,

V1,V6 - sphere valves.

Figure 1: Schematic diagram of the experimental apparatus:

\section{Total Phenolic Contents}

The total phenolic contents of the different extracts of $S$. molle were determinated by the FolinCiocalteu method modified by Shetty et al. (1995). Briefly, $1 \mathrm{~mL}$ of the sample extract was transferred into a test tube and mixed with $1 \mathrm{~mL}$ of $99 \%$ ethanol and $5 \mathrm{~mL}$ of distilled water. To each sample, $0.5 \mathrm{~mL}$ of $50 \% \quad(\mathrm{v} / \mathrm{v})$ Folin-Ciocalteu reagent (Proton Química) was added and mixed. After $5 \mathrm{~min}, 1 \mathrm{~mL}$ of $5 \% \mathrm{Na}_{2} \mathrm{CO}_{3}(\mathrm{w} / \mathrm{v})$ was added to the reaction mixture and allowed to stand for $90 \mathrm{~min}$. The absorbance was read at $725 \mathrm{~nm}$, using a Biospectro SP 220 UV-VIS spectrometer. Three replicates of each sample were analyzed and their average was used as the final reading The standard curve was established using various concentrations of gallic acid (Sigma-Aldrich) in 99\% ethanol (Merck) and results were expressed as gallic acid equivalent (GAE) per g (dried sample).

\section{Mathematical Modeling}

Several mathematical models have been employed to simulate supercritical fluid extraction from vegetable matrixes (Grosso et al., 2010; Steffani et al., 2006; Silva et al., 2008). In this work, the mathematical model used to fit the experimental data was that proposed by Sovová (2005). In this model, the solute is assumed to be homogeneously distributed in the solid particles. The readily accessible solute from broken cells near the surface is transferred directly to the fluid-phase, while the solute from intact cells diffuses internally and then to the fluid-phase (Sovová, 2005).
The choice of the adequate model was done by analysis of the experimental behavior.

Based on the hypothesis that extraction curves are associated with the non-existence of interaction between solute and matrix, the model used is described by the following equation:

$$
\begin{array}{lll}
e=\mathrm{qy}_{\mathrm{s}} & \text { for } & 0 \leq \mathrm{q} \leq \mathrm{q}_{\mathrm{c}} \\
\mathrm{e}=\mathrm{x}_{\mathrm{u}}\left[1-\mathrm{C}_{1} \exp \left(-\mathrm{C}_{2} \mathrm{q}\right)\right] & \text { for } & \mathrm{q}>\mathrm{q}_{\mathrm{c}}
\end{array}
$$

where e is the extraction yield $\left(\mathrm{kg}_{\text {extract }}\right) /\left(\mathrm{kg}_{\text {insoluble }}\right.$ solid); $\mathrm{q}$ is the relative amount of the solvent passed $\left(\mathrm{kg}_{\text {solvent }}\right) /\left(\mathrm{kg}_{\text {insoluble }}\right.$ solid $) ; \mathrm{y}_{\mathrm{s}}$ is the solubility $\left(\mathrm{kg}_{\text {extract }}\right) /\left(\mathrm{kg}_{\text {solvent }}\right) ; \mathrm{x}_{\mathrm{u}}$ is the concentration in the untreated solid $\left(\mathrm{kg}_{\text {extract }}\right) /\left(\mathrm{kg}_{\text {insoluble solid }}\right)$. In this formulation, the fitting of the first part of equilibrium extraction curve is carried out with a straight line of slope $\mathrm{y}_{\mathrm{s}}$. The curve described by

Eq. (2) is associated with the second period of the extraction and the estimated grinding efficiency, $r$, and solid phase coefficient, $\mathrm{k}_{\mathrm{s}} \mathrm{a}_{\mathrm{s}}$, depend on the constants $\mathrm{C}_{1}, \mathrm{C}_{2}$ and the coordinate $\mathrm{q}_{\mathrm{c}}$ at the crossing point:

$$
\begin{aligned}
& \mathrm{r}=\mathrm{x}_{\mathrm{u}}\left[1-\mathrm{C}_{1} \exp \left(-\mathrm{C}_{2} \frac{\mathrm{q}_{\mathrm{c}}}{2}\right)\right] \\
& \mathrm{k}_{\mathrm{s}} \mathrm{a}_{\mathrm{s}}=(1-\mathrm{r})(1-\varepsilon) \dot{\mathrm{Q}} \mathrm{C}_{2} / \mathrm{N}_{\mathrm{m}}
\end{aligned}
$$

where $\varepsilon$ is the bed porosity, $\mathrm{Q}$ is the solvent flow rate $(\mathrm{kg} / \mathrm{s})$ and $\mathrm{N}_{\mathrm{m}}$ is the charge of insoluble solid $(\mathrm{kg})$. 
The adjustable parameters $\left(\mathrm{C}_{1}, \mathrm{C}_{2}\right.$ and $\left.\mathrm{y}_{\mathrm{s}}\right)$ were estimated using the software EMSO - Environment for Modeling, Simulation and Optimization (Soares and Secchi, 2003).

\section{RESULTS AND DISCUSSIONS}

The volatile compounds identified in the essential oil of $S$. molle are presented in Table 1 . The main compounds identified in the oil obtained by supercritical fluid extraction (Figure 2) were sabinene $(5.85 \%)$, limonene $(41.37 \%)$, (E)-caryophyllene $(15.60 \%)$, bicyclogermacrene $(11.59 \%)$, germacrene D (8.86\%), and spathulenol (4.03\%).

The essential oil chemical composition extracted from aromatic plants depends on several factors: phenologic state, geographic factors (location), ecologic factors (habitat), genetic variability (chemotype), the extraction process, etc. (Bandoni, 2000). Due to these factors, the chemical composition of the Schinus molle essential oil presented in Table 1 differs from results published by Marongiu et al. (2004), but is similar to results obtained by Santos et al. (2007). This similarity can be attributed to the geographical factor and the chemotype of the plant studied.

The total phenolic content of the non-volatile extracts was analyzed by a modified FolinCiocalteu method and the results are shown in Table 2. From these results, it was possible to observe that the total phenolic content changes with the pressure at $323.15 \mathrm{~K}$.

The unknown parameters in the model presented above were adjusted by using the experimental data from the pilot supercritical equipment. The numerical values for these parameters are presented in Table 3.

Table 1: GC-MS of volatile oil extracted by supercritical fluid extraction (9 MPa and 323.15 K)

\begin{tabular}{|c|c|c|}
\hline Compound & $\mathbf{R} \mathbf{I}^{\mathbf{a}}$ & $\%$ Area $^{b}$ \\
\hline$\alpha$-thujene & 922 & 0.03 \\
\hline$\alpha$-pinene & 927 & 2.70 \\
\hline sabinene & 971 & 5.85 \\
\hline myrcene & 989 & 0.83 \\
\hline p-cymene & 1023 & 0.08 \\
\hline limonene & 1028 & 41.37 \\
\hline$\gamma$-terpinene & 1057 & 0.04 \\
\hline terpinolene & 1085 & 0.03 \\
\hline linalool & 1099 & 0.06 \\
\hline cis-p-menth-2-en-1-ol & 1118 & 0.05 \\
\hline borneol & 1159 & 0.03 \\
\hline terpinen-4-ol & 1174 & 0.06 \\
\hline$\alpha$-terpineol & 1188 & 0.02 \\
\hline trans-carveol & 1216 & 0.07 \\
\hline carvone & 1240 & 0.08 \\
\hline carvacrol & 1294 & 0.85 \\
\hline (E)-caryophyllene & 1414 & 15.60 \\
\hline trans- $\alpha$-bergamotene & 1432 & 0.07 \\
\hline$\alpha$-humulene & 1447 & 1.04 \\
\hline allo-aromandrene & 1455 & 0.30 \\
\hline germacrene D & 1476 & 8.86 \\
\hline bicyclogermacrene & 1492 & 11.59 \\
\hline germacrene A & 1501 & 0.10 \\
\hline$\delta$-cadinene & 1519 & 0.36 \\
\hline germacrene B & 1553 & 0.03 \\
\hline palustrol & 1561 & 0.11 \\
\hline spathulenol & 1573 & 4.03 \\
\hline caryophyllene oxide & 1577 & 2.24 \\
\hline rosifoliol & 1597 & 0.06 \\
\hline shyobunol & 1680 & 0.14 \\
\hline
\end{tabular}

${ }^{a}$ The components are reported according to their elution order on HP-5MS. ${ }^{b}$ Relative proportions of the essential oil constituents were xpressed as percentages obtained by peak-area normalization, all relative response factors being taken as one. 


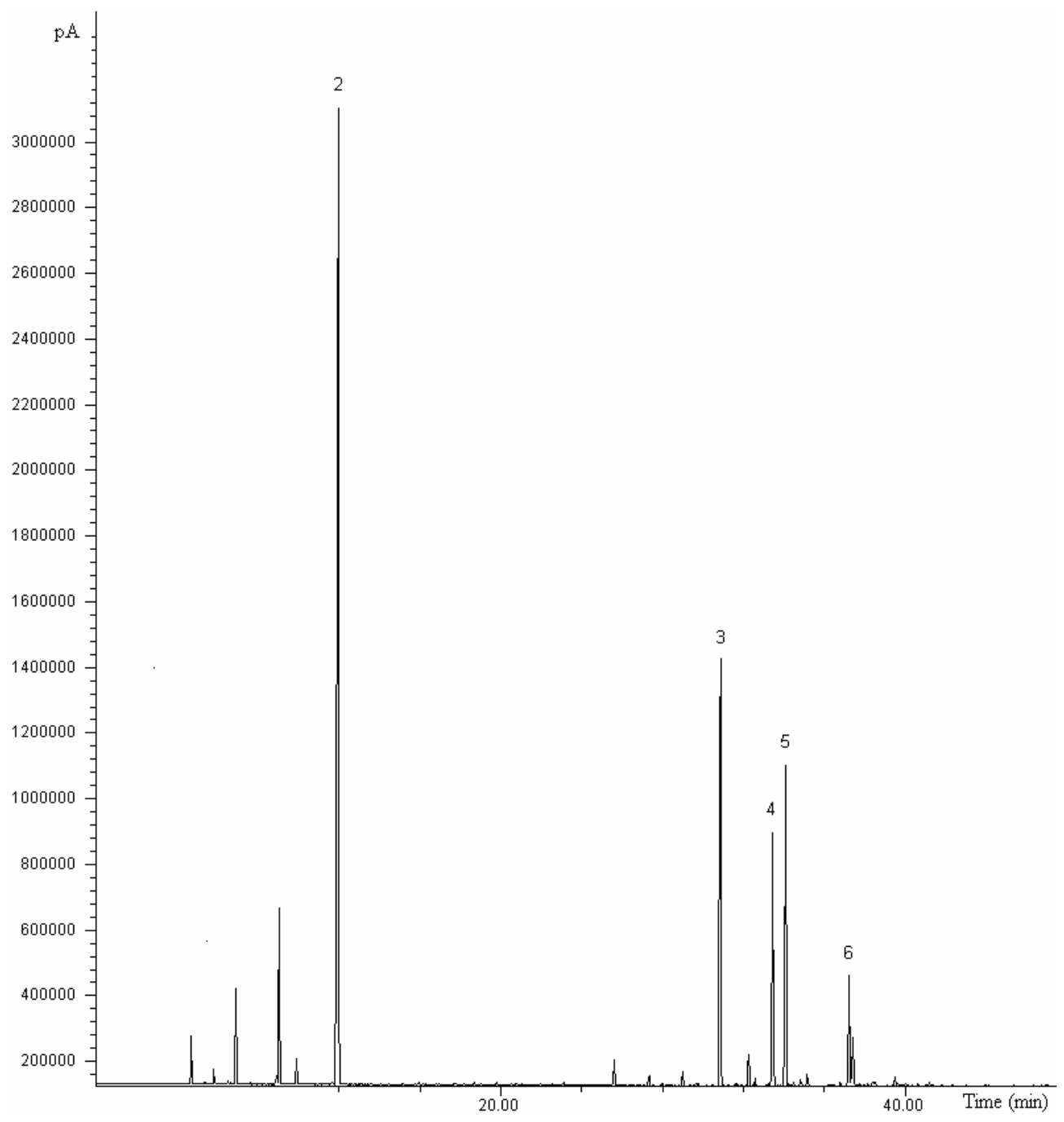

Figure 2: GC/MS chromatogram for Schinus molle oil obtained by SFE at $9 \mathrm{MPa}$ and $323.15 \mathrm{~K}$ : sabinene(1), limonene(2), E-caryophyllene(3); D-germacrene(4), byciclogremacrene(5), spathulenol(6).

Table 2: Content of total phenolic at $323.15 \mathrm{~K}$

\begin{tabular}{|c|c|}
\hline Pressure & $\begin{array}{l}\text { Gallic acid equivalents } \\
\text { (mg) per g (dried sample) }\end{array}$ \\
\hline $10 \mathrm{MPa}$ & $31.91 \pm 3.93$ \\
$12 \mathrm{MPa}$ & $57.11 \pm 3.99$ \\
$15 \mathrm{MPa}$ & $64.16 \pm 2.44$ \\
$20 \mathrm{MPa}$ & $64.16 \pm 3.99$ \\
\hline
\end{tabular}

Table 3: Parameters of extraction curves fitted to experimental data for $S$. molle at $323.15 \mathrm{~K}$.

\begin{tabular}{|c|c|c|c|}
\hline Pressure & $\mathbf{y}_{\mathbf{s}}$ & $\mathbf{C}_{\mathbf{1}}$ & $\mathbf{C}_{\mathbf{2}}$ \\
\hline $09 \mathrm{MPa}$ & 0.0067 & 3.185 & 0.082429 \\
$10 \mathrm{MPa}$ & 0.0174 & 1.893 & 0.027262 \\
$12 \mathrm{MPa}$ & 0.0321 & 11.002 & 0.064432 \\
$15 \mathrm{MPa}$ & 0.0615 & 18.850 & 0.069810 \\
$20 \mathrm{MPa}$ & 0.0550 & 38.001 & 0.093088 \\
\hline
\end{tabular}


The experimental data and the results for the mathematical modeling of the supercritical extraction at $323.15 \mathrm{~K}$ for the pressure range between $9 \mathrm{MPa}$ and $20 \mathrm{MPa}$ are shown in Figure 3. These parameters were estimated by minimization of the sum of squares of errors between the experimental data and mathematical results obtained by means of the model using the software EMSO (Soares and Secchi, 2003).

The curves for the mathematical model implementation are shown in Figure 2. The ordinate represents the " $\mathrm{e}$ " parameter, the dimensionless extract quantity, and the abscissa represents the extraction time, expressed as a function of the total amount of the solvent used. Agreement between the mathematical model used and the experimental data was observed. The small variations can be the result of the numerical method applied to adjust the parameters, as well as the variations inherent to experimental data. It is important to mention the hypothesis of the non-existence of interaction between solute and matrix, causing the equilibrium fluid-phase concentration to be independent of the solute concentration in broken cells, i.e., the equilibrium fluid-phase concentration is constant and equal to solubility. This assumption was adopted in mathematical modeling by various authors (Sovová, 1994; Stastová et al., 1996).

The mathematical model used here is based on the concept of broken and intact cells; it is suited to fit experimental data whose behavior is described by two temporal phases, the first one governed by phase equilibrium and the second one governed by internal diffusion from particles. In the first phase, a straight line reproduces the behavior of the extraction curve. The solubility is established from the slope of this line for all extraction conditions carried out, and it is observed to increase with the pressure. At $9 \mathrm{MPa}$, essential oil was obtained, while at other pressures heavier compounds were extracted. In the second phase, a curve represents the extraction and the mathematical modeling involves the parameters $\mathrm{C}_{1}$ and $\mathrm{C}_{2}$. The parameter $\mathrm{C}_{2}$ defined by Eq. (4) is associated with the solid-phase coefficient. The solid-phase coefficient and, consequently, the parameter $\mathrm{C}_{2}$ increases with pressure, as can be observed in Table 3. This fact is in accord with the literature (Grosso et al., 2010). The parameter $C_{1}$, defined by Eq. (3), involves the gridding efficiency, associated with the fraction of broken cells and the crossing point between the two temporal phases. It is important to remember that the crossing point is a fictional time when mass transfer from intact cells begins, also known as the shift of the second part of extraction curve. Considering that, in this work, two type of extracts were obtained (oil at $9 \mathrm{MPa}$ and heavier extract from $10 \mathrm{MPa}$ ), the parameter $\mathrm{C}_{1}$ showed an increase with the pressure.

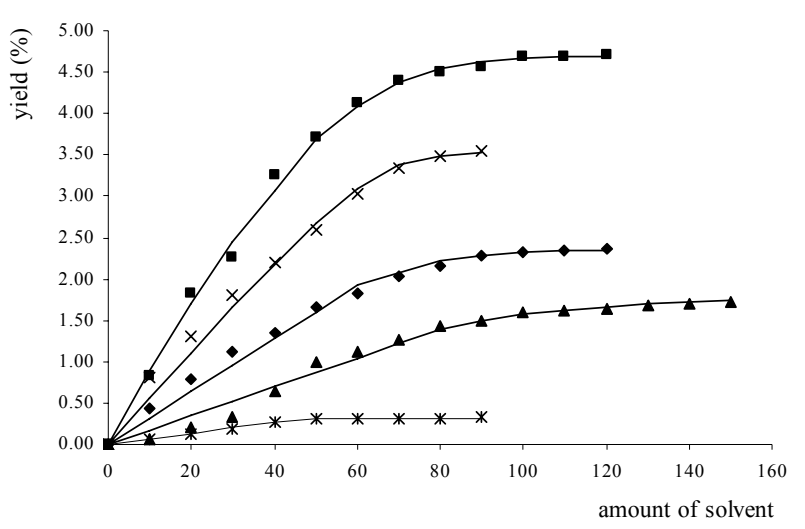

Figure 3: $\mathrm{CO}_{2}$ supercritical extraction yield curves vs. time at $323.15 \mathrm{~K}$. Pressure conditions: (Ж) $9 \mathrm{MPa}$, (ム) $10 \mathrm{MPa}$; •) $12 \mathrm{MPa}$; (•) $15 \mathrm{MPa}$; (×) $20 \mathrm{MPa}$; (-) Eqs. (1) and (2) with parameters from Table 3.

Extracts with diverse compositions were obtained under different pressure conditions due to the complex composition of the plant matrix. At a pressure of $9 \mathrm{MPa}$, extracts consisting basically of terpenes and sesquiterpenes were obtained. For the condition of $10 \mathrm{MPa}$, the same compounds were obtained together with oil-resins and phenolic compounds. From $12 \mathrm{MPa}$, the phenolic concentration increased in the extracts when supercritical carbon dioxide was used as solvent. In relation to the behavior of supercritical extraction of the non-volatile compounds, the pressure of $15 \mathrm{MPa}$ is indicated for obtaining the best results for both the extract yield (Figure 3) and total phenolic content (Table 2), compared with the experiments conducted at other pressures. Thus, the yield increases with pressure until it reaches $15 \mathrm{MPa}$ and, from this condition on, there is a reduction of extract yield. Analogous behavior, i.e., a yield reduction with a pressure increase, was also obtained by Machmudah et al. (2007) for total extraction of rosehip seed oil, by Leal et al. (2010) for antioxidant activity of Pfaffia paniculata extracts, and by Cassel et al. (2010) for total extraction of Ilex paraguariensis. This behavior can be attributed to the change in the extract composition with the variation of extraction pressure, because the pressure increase at constant temperature promotes a solvent density increase, which allows the solvent to extract higher molecular weight compounds from the vegetable matrix. 


\section{CONCLUSIONS}

The use of supercritical fluid extraction to obtain volatile and non-volatile extracts of $S$. molle, from a single raw material, is part of a proposal for a sustainable use of this plant that exists in abundance in southern Brazil and whose extracts have proven activities. Therefore, this study investigated the supercritical extraction process of volatile and nonvolatile compounds of $S$. molle, concluding that the condition most suitable for obtaining non-volatile extracts is $15 \mathrm{MPa}$ and $323.15 \mathrm{~K}$, while that for obtaining volatile oils is $9 \mathrm{MPa}$ and $323.15 \mathrm{~K}$, confirming previous results presented by Marongiu et al. (2004).

Good results were observed with respect to the simulated extraction curves obtained from the mathematical model when compared with the experimental data. The determination of the values of the adjustable parameters of the model provides important knowledge about the supercritical extraction of $S$. molle. Finally, the model parameter evaluation reported in this work on the pilot scale permits one to evaluate the extraction time required to obtain a given yield and should be useful for the scale-up of the extraction process and/or during industrial operation.

\section{NOMENCLATURE}

$\begin{array}{ll}\mathrm{C}_{1}, \mathrm{C}_{2} & \begin{array}{l}\text { Constants } \\ \mathrm{e}\end{array} \\ \mathrm{k}_{\mathrm{s}} \mathrm{a}_{\mathrm{s}} & \begin{array}{l}\text { Extraction yield } \\ \text { Solid phase } \\ \text { coefficient }\end{array} \\ \mathrm{N}_{\mathrm{m}} & \begin{array}{l}\text { Insoluble solid } \\ \mathrm{Q}\end{array} \\ & \begin{array}{l}\text { Relative amount of the } \\ \text { solvent passed }\end{array} \\ \mathrm{Q} & \text { Solvent flow rate } \\ \mathrm{r} & \text { Grinding efficiency } \\ \mathrm{x}_{\mathrm{u}} & \text { Solute content in the } \\ & \text { untreated solid } \\ \mathrm{y}_{\mathrm{s}} & \text { Solubility }\end{array}$

$\mathrm{kg} / \mathrm{kg}$
$\mathrm{s}^{-1} \cdot \mathrm{m}^{-1}$
$\mathrm{~kg}$
$\mathrm{~kg} / \mathrm{kg}$
$\mathrm{kg} / \mathrm{s}$
$\mathrm{kg} / \mathrm{kg}$
$\mathrm{kg} / \mathrm{kg}$

Greek Letters

$\varepsilon \quad$ Porosity

\section{ACKNOWLEDGEMENTS}

The authors thank CNPq and Programa
CYTED.

\section{REFERENCES}

Adams, R. P., Identification of Essential Oils Components by Gas Chromatography/Mass Spectrometr. $4^{\text {th }}$ Edn., Allured. Carol Stream, IL, USA (2007).

Azevedo A. B. A., Mazzafera P., Mohamed R. S., Melo S. A. B. V., Kieckbusch T. G., Extraction of caffeine, chlorogenic acids and lipids from green coffee beans using supercritical carbon dioxide and co-solvents. Braz. J. Chem. Eng., 25, 543552 (2008).

Bandoni, A., Los Recursos Vegetales Aromáticos en Latinoamérica. Editorial de la Universidad Nacional de La Plata. Argentina, p. 417 (2000).

Bendaoud, H., Romdhane, M., Souchard, J. P., Cazaux, S., and Bouajila, J., Chemical composition and anticancer and antioxidant activities of Schinus molle L. and Schinus terebinthifolius Raddi Berries Essential Oils. J. Food Science, 75, (6), 466-472 (2010).

Brennecke, J. F., Eckert, C. A., Phase equilibria for supercritical fluid process design. AIChE J., v. 35, n. 09, pp. 1409-1427 (1989).

Cardozo, Jr. E. L., Cardozo-Filho, L., FerrareseFilho, O. and Zanoelo, E. F., Selective liquid $\mathrm{CO}_{2}$ extraction of purine alkaloids in different Ilex paraguariensis progenies grown under environmental influences. J. Agric. Food Chem., 55, 6835-6841 (2007).

Cassel, E., Vargas, R. M. F., Brun, G. W., Almeida, D. E., Cogoi, L., Ferraro, G. and Filip, R., Supercritical fluid extraction of alkaloids from Ilex paraguariensis St. Hil. J. Food Eng., 100, 656-661 (2010).

Davies, N. W., Gas chromatographic retention indexes of monoterpenes and sesquiterpenes on methyl silicone and Carbowax 20M phases. J. Chromatogr., 503, 1-24 (1990).

Ferrero, A. A., Werdin, González, J. O., Sánchez Chopa, C. and Alzogaray, R. A., Biological activity of Schinus molle on Triatoma infestans. Fitoterapia, 77, 381-383 (2006).

Ferrero, A. A., Sánchez Chopa, C., Werdin González, J. O. and Alzogaray, R. A., Repellence and toxicity of Schinus molle extracts on Blattella germanica. Fitoterapia, 78, 311-314 (2007).

Grosso, C., Coelho J. P., Pessoa, F. L. P, Fareleira, J. M. N. A., Barroso J. G., Urieta J. S., Palavra A. F. and Sovova H., Mathematical modeling of supercritical $\mathrm{CO}_{2}$ extraction of volatile oils from aromatic plants. Chem. Eng. Science, 65, 35793590 (2010). 
Huerta, A., Chiffelle, I., Puga K., Azúa, F. and Araya, J. E., Toxicity and repellence of aqueous and ethanolic extracts from Schinus molle on elm leaf beetle Xanthogaleruca luteola. Crop Protect, 29, 1118-1123 (2010).

Hayouni, E. A., Chraief, I., Abedrabba, M., Bouix, M., Leveau J. Y., Mohammed, H. and Hamdi, M., Tunisian Salvia officinalis L. and Schinus molle L. essential oils: Their chemical compositions and their preservative effects against Salmonella inoculated in minced beef meat. Internat. J. Food Microbiol., 125, 242-251 (2008).

Jennings, W. and Shibamoto, T., Qualitative analysis of fragrance volatiles by glass capillary gas chromatography. Academic Press: New York (1980).

Leal, P. F., Kfouri, M. B., Alexandre, F. C., Fagundes, F. H. R., Prado, J. M., Toyama, M. H. and Meireles, M. A. A., Brazilian Ginseng extraction via LPSE and SFE: Global yields, extraction kinetics, chemical composition and antioxidant activity. J. Supercritical Fluids, 54, 38-45 (2010).

Machmudah, S., Kawahito, Y, Sasaki, M. and Goto, $\mathrm{M}$, Supercritical $\mathrm{CO}_{2}$ extraction of rosehip seed oil: Fatty acids composition and process optimization. J. Supercritical Fluids, 41, 421-428 (2007),

Marongiu, B., Piras, A., Porcedda, S., Casu, R. and Pierucci, P., Chemical composition of the oil and supercritical $\mathrm{CO}_{2}$ extract of Schinus molle L. Flavour and Fragrance J., 19, 554-558 (2004).

Marrone, C., Poletto, M., Reverchon, E. and Stassi, A., Almond oil extraction by supercritical $\mathrm{CO}_{2}$ : experiments and modelling. Chem. Eng. Science, 53, 3711-3718 (1998).

Martinez, J, Monteiro, A. R., Rosa, P. T. V., Marques, M. O. M. and Meireles, M. A.,A., Multicomponent model to describe extraction of ginger oleoresin with supercritical carbon dioxide. Ind. Eng. Chem. Research, 42, 10571063 (2003).

Marzouk, M. S., Moharram, F. A., Haggag, E. G., Ibrahim, M. T., and Badary, O. A., Antioxidant Flavonol Glycosides from Schinus molle. Phytotherapy Research, 20, 200-205 (2006).

Reverchon, E., Mathematical modelling of supercritical extraction of sage oil. AIChE Journal, 42, 1765-1771, (1996).

Santos, A. C. A., Rossato, M., Agostini, F., Almeida, M. L., Pauletti, G. F., Serafini, L. A., Moyna, P. and Dellacassa, E., Caracterização química de populações de Schinus molle L. do Rio Grande do Sul, Ver. Bras. de Biociências, 5, 1014-1016 (2007). Shetty, K., Curtis, O. F., Levin, R. E., Wikowsky, R. and Ang, W., Prevention of verification associated with in vitro shoot culture of oregano (Origanum vulgare) by Pseudomonas spp. J. Plant Physiol., 147, 447-451 (1995).

Silva, C. F., Mendes, M. F., Pessoa, F. L. P. and Queiroz, E. M., Supercritical carbon dioxide extraction of macadamia (Macadamia integrifolia) nut oil: experiments and modeling. Braz. J. Chem. Eng., 25, 175-181 (2008).

Soares, R. P. and Secchi, A. R., EMSO: A new environment for modeling, simulation and optimization. In: European Symposium on Computer Aided Process Engineering. Lappenranta: Anais (2003).

Sovová, H., Rate of the vegetable oil extraction with supercritical $\mathrm{CO}_{2}$. I. Modelling of extraction curves. Chem. Eng. Science, 49, 409-414 (1994).

Sovová, H., Mathematical model for supercritical fluid extraction of natural products and extraction curve evaluation. J. Supercr. Fluids, 33, 35-52 (2005).

Stastová, J., Jez, J., Bartlová, M., Sovová, H., Rate of the vegetable oil extraction with supercritical CO2. III. Extraction from sea buckthorn. Chem. Eng. Science, 51, 4347-4351 (1996).

Steffani, E., Atti-Santos, A. C., Atti-Serafini, L. and Pinto, L. T., Extraction of Ho-Sho (Cinnamomum camphora Nees and Eberm var. Linaloolifera fujita) essential oil with supercritical $\mathrm{CO}_{2}$ : experiments and modeling. Braz. J. Chem. Eng., 23, 259-266 (2006).

Taylor, L.T., Supercritical Fluid Extraction. John Wiley \& Sons Inc., New York (1996).

Vargas, R. M. F., Cassel, E., Gomes, G. M. F., Longhi, L. G. S., Serafini, L. A. and Santos, A. C. A., The carqueja essential oil supercritical extraction: experiments and modeling. Braz. J. Chem. Eng., 23, 375-382 (2006).

Wimalaratne, P., Slessor, K., Borden, J., Chong, L. and Abate, T., Isolation and identification of house fly, Musca domestica L., repellents from pepper tree, Schinus molle L. J. Chem. Ecol., 22, 49-59 (1996).

Zahed, N., Hosni, K., Brahim, N. B., Kallel, M. and Sebei, H., Allelopathic effect of Schinus molle essential oils on wheat germination. Acta Physiol. Plant, 32, 1221-1227 (2010). 